\title{
The Influence of Soil Organic Matter on DNA Adsorptions on Andosols
}

\author{
KAZUTOSHI SAEKI ${ }^{1}$, and MASAO SAKAI ${ }^{2 *}$ \\ ${ }^{1}$ Biotron Institute, Kyushu University, Hakozaki, 6-10-1 Higashi-ku, Fukuoka 812-8581, Japan; and ${ }^{2}$ Faculty of \\ Agriculture, Kagoshima University, 1-21-24 Korimoto, Kagoshima 890-0065, Japan
}

(Received February 23, 2009-Accepted April 9, 2009—Published online April 29, 2009)

The influence of soil organic matter on DNA adsorption in andosols was investigated using various andosol samples including hydrogen peroxide $\left(\mathrm{H}_{2} \mathrm{O}_{2}\right)$-treated, heated $\left(400^{\circ} \mathrm{C}\right)$, and slurry-added soils. Remarkably less DNA was adsorbed in the slurry-added soil than the original soil. The increase in soil organic matter with the addition of slurry had an obvious negative influence on the adsorption. The decrease in organic matter with $\mathrm{H}_{2} \mathrm{O}_{2}$ treatment slightly raised DNA adsorption per unit weight. Adsorption maxima estimated from a simple Langmuir equation were higher in the samples removed of organic matter by the $\mathrm{H}_{2} \mathrm{O}_{2}$ treatment and heating at $400^{\circ} \mathrm{C}$ than in the untreated soil, although surface area was greatly decreased by both treatments. There was no correlation between the total carbon (T-C) content and the estimated DNA adsorption maxima of any of the soil samples. These results suggest little contribution of soil organic matter to DNA adsorption in andosols.

Key words: DNA adsorption, soil organic matter, andosols, organic matter removing, manure slurry application

Most bacteria in soil are not cultivable with artificial media (21). Therefore, in several decades, these nonculturable bacteria have been detected using methods based on the hybridization or PCR amplification of DNA sequences extracted directly from soils. It is more difficult to extract DNA from volcanic ash soils (andosol), wide-spread in Japan, than from other soil types $(6,8)$. This has been a major problem in analyses of the composition and diversity of soil microbial communities with culture-independent methods. Thus, understanding how DNA is adsorbed by soil particles is important for developing efficient methods of extraction. Many researches have used 2:1 layer phyllosilicates such as montmorillonite as adsorptive particle to study DNA adsorption in soils $(4,5,9,10,16)$. However, the results obtained with phyllosilicates alone are not enough to understand the behavior of DNA molecules in variablecharged soils such as andosols. Moreover, there have been few studies on DNA adsorption in natural soils $(13,14)$.

In a previous study (19), DNA adsorption in soils was investigated using andosol, fluvisol, and acrisol samples taken in Japan. The andosol was found to adsorb much more DNA than the fluvisol or acrisol. Next, the contribution of soil organic matter to the adsorption process was evaluated by treating soil samples with hydrogen peroxide $\left(\mathrm{H}_{2} \mathrm{O}_{2}\right)$. The decrease in organic matter little affected DNA adsorption per unit weight, implying that soil organic matter may not be related to DNA adsorption in soil.

To better understand the contribution of soil organic matter to the adsorption of DNA by andosol particles, the effects of hydrogen peroxide treatment were examined. However, a small portion of organic matter is resistant even to $\mathrm{H}_{2} \mathrm{O}_{2}$. All organic matter needs to be removed from soil to study DNA adsorption in organic matter-free soil particles. In a previous

\footnotetext{
* Corresponding author. E-mail: msakai@ms.kagoshima-u.ac.jp;
} Tel: +81-99-285-8661. study, an andosol heated at $400^{\circ} \mathrm{C}$ was used to investigate inorganic anion adsorption (17). We compared DNA adsorption between the heated andosol and untreated soil to elucidate the contribution of soil organic matter to DNA adsorption. Furthermore, to investigate influences of an increase in soil organic matter content, we compared DNA adsorption between a manure slurry-amended andosol and untreated soil from neighboring fields.

\section{Materials and Methods}

\section{Soil samples}

Samples of four surface humic andosols collected in Japan were used: Chiran soil (CR soil) and Tanashi soil (TA soil) to investigate the effects of lowering soil organic content on DNA adsorption, and Miyakonojyo soil (MY soil) and MY soil amended with a large amount of manure slurry (MY+slurry soil) to examine the effects of increasing soil organic content on DNA adsorption. CR soil was a thick humic andosol taken from the top $10 \mathrm{~cm}$ of a field in Minamikyushu, Kagoshima. TA soil was a humic andosol from the 0-20 cm layer of a forest in Nishi-tokyo, Tokyo. The properties of the soil were described previously (18). MY soil was a humic andosol taken from the 0-20 cm layer of a field in Miyakonojyo, Miyazaki. MY+slurry soil was collected from the $0-20 \mathrm{~cm}$ layer of a field neighboring the MY field. This field has been amended with slurry at $60 \mathrm{t}$ per $10 \mathrm{a}$. Relevant physicochemical data for the soils is given in Table 1 . These soils were classified as Typic Meranudands.

\section{Pretreatments of the soil samples}

Untreated soils. The raw soil samples were sieved (pore size, 2 $\mathrm{mm}$ ), then added with dilute $\mathrm{NaOH}$ solution to $\mathrm{pH} 6$, and washed several times with ultra-pure water (UPW). Finally, they were freeze-dried and stored until the adsorption experiments.

Hydrogen peroxide-treated $\left(\mathrm{H}_{2} \mathrm{O}_{2}\right.$-treated) soils. The freezedried soil samples were added with $7 \% \mathrm{H}_{2} \mathrm{O}_{2}$ solution, then heated at $95^{\circ} \mathrm{C}$ for more than 2 hours (17). The suspensions were centrifuged at $16,000 \times \mathrm{g}$ for $10 \mathrm{~min}$, and the residue adjusted with a dilute $\mathrm{NaOH}$ solution to $\mathrm{pH} 6$ were washed several times with UPW, then freeze-dried. 
Table 1. Chemical and physical properties of the andosol samples

\begin{tabular}{|c|c|c|c|c|c|}
\hline & Sample MY & Sample MY+slurry & Sample TA & Sample CR & Sample KB* \\
\hline Location & \multicolumn{2}{|c|}{ Miyazaki } & Tokyo & Kagoshima & Kumamoto \\
\hline Clay content (\%) & \multicolumn{2}{|c|}{10.6} & 23.9 & 23.5 & 13.0 \\
\hline Texture & \multicolumn{2}{|c|}{ Sandy loam } & Clay loam & Clay loam & Sandy loam \\
\hline $\mathrm{pH}\left(\mathrm{H}_{2} \mathrm{O}\right)$ & 5.3 & 6.4 & 5.3 & 6.1 & 6.9 \\
\hline $\mathrm{pH}(\mathrm{KCl})$ & 4.9 & 5.2 & 4.5 & 5.3 & 6.0 \\
\hline Total carbon content $(\%)$ & 2.4 & 8.3 & 8.3 & 12.0 & 9.6 \\
\hline
\end{tabular}

* The data for Sample KB was quoted from our previous study (19).

$400^{\circ} \mathrm{C}$ heated soils. TA soil samples were heated at $400^{\circ} \mathrm{C}$ for 4 hrs in an electric oven (17). The solid added with UPW was adjusted to $\mathrm{pH} 6$, then washed several times with UPW. The centrifuged solid samples were finally freeze-dried.

DNA sample

This study used salmon sperm DNA (average size, 1,000 bp) supplied by Invitrogen (Carlsbad, CA, USA). The DNA solution was diluted to a suitable concentration with UPW for the adsorption experiments.

\section{DNA Adsorption Experiments}

The diluted DNA solution (volume: $1.0 \mathrm{~mL}$ ) was added to $0.1 \mathrm{-g}$ aliquots of autoclaved soil samples. The initial DNA concentration ranged from 0 to $400 \mathrm{mg} \mathrm{L}^{-1}$. The suspension was shaken for 2 hours in an air-conditioned room at $25 \pm 1^{\circ} \mathrm{C}$ and centrifuged at $16,000 \times \mathrm{g}$ for $20 \mathrm{~min}$. The DNA in the supernatant was quantified fluorometrically using the PicoGreen quantification method (7). The amount of DNA adsorbed was calculated from the difference between the amount added and the amount remaining in the solution.

DNA adsorption by a variety of solid particles is affected by factors such as the solution's $\mathrm{pH}$ and ionic strength $(1,11)$. However, because each soil sample was adjusted to $\mathrm{pH} 6$ and repeatedly washed with UPW, we did not consider these factors to be relevant in the adsorption experiments.

The affinity of the soil samples for DNA was determined with maximum adsorption $\left(A_{\max }\right)$ from the Langmuir equation, shown below;

$A=\frac{k \cdot A_{\max } \cdot C}{1+k \cdot C}$

where $A$ is each DNA's adsorption, $k$ is an adsorptive equilibrium constant, and $C$ is each DNA's equilibrium concentration. From Eq. [1], we lthen obtain,

$\frac{C}{A}=\frac{1}{k \cdot A_{\max }}+\frac{1}{A_{\max }} \cdot C$

Maximum adsorption can be calculated approximately by applying the empirical adsorptive data to Eq. [2]. The significance of correlation coefficients in regression analyses was evaluated with a $t$-test.

\section{Results}

Comparison of DNA adsorption among a variety of andosols

Fig. 1 shows DNA adsorption in the untreated samples of MY, MY+slurry, TA, and CR soils. DNA adsorption in the andosol is also indicated in Table 3 with each $A_{\max }$ value estimated from the Langmuir equation. For comparison, data (19) on another humic andosol (KB soil), a fluvisol and an acrisol are also listed in Table 3. Almost all of the DNA ( $\left.<200 \mathrm{mg} \mathrm{L}^{-1}\right)$ was adsorbed by untreated MY soil particles. The adsorption increased in proportion with the DNA concentration in untreated TA soil. The adsorption maxima in the untreated andosols estimated with the Langmuir equation decreased in the order: KB soil $>$ MY soil $>$ TA soil $>$ CR soil (Table 3). This order can not be explained simply by the total carbon (T-C) content, clay fraction content and $\mathrm{pH}$ of the soils, listed in Table 1. Ogram et al. $(13,14)$, using three soils taken in the USA, also found that DNA adsorption had no correlation with the chemical and physical properties of the soils.

The effects of an increase in soil organic content on DNA adsorption were evaluated by comparing MY soil with MY+slurry soil (Fig. 1). The total carbon content of MY+slurry soil was $8.3 \%$, whereas that of MY soil was $2.4 \%$ (Table 1). The DNA adsorption by MY+slurry soil was remarkably less than that by MY soil. The increase in soil organic matter due to the slurry had an obvious negative influence on DNA adsorption in the soil. This result was consistent with the finding that almost all DNA was extracted from the same MY+slurry soil in the study of microbial communities while much DNA could not be extracted from the untreated MY soil (Sakai, personal communication).

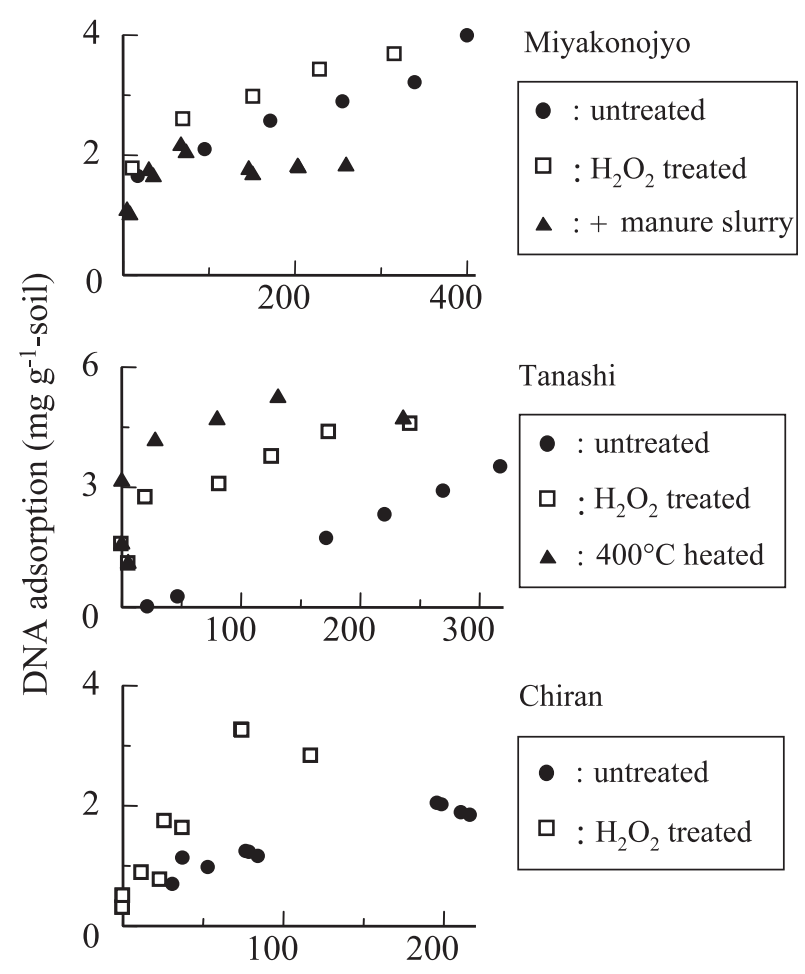

DNA concentration $\left(\mathrm{mg} \mathrm{L}^{-1}\right)$

Fig. 1. DNA adsorption in each treated andosol. 
The effect of removing organic matter on DNA adsorption in the andosols

The effects of soil organic matter on DNA adsorption in the soils were investigated by reducing the organic matter contents of the soils with $\mathrm{H}_{2} \mathrm{O}_{2}$ treatment (Fig. 1). Total carbon content decreased with the $\mathrm{H}_{2} \mathrm{O}_{2}$ treatment from 2.4 to $0.12 \%$ in MY soil, from 8.3 to $2.2 \%$ in TA soil and from 12.0 to $0.9 \%$ in CR soil (Table 1 and 2). Since these soils seem to contain little carbonate, the decrease in T-C contents can be regarded as a decrease in soil organic matter. DNA adsorption was greater in the $\mathrm{H}_{2} \mathrm{O}_{2}$-treated $\mathrm{MY}$ and $\mathrm{CR}$ soils than in the untreated soils (Fig. 1). The estimated DNA adsorption maxima slightly increased from $4.17 \mathrm{mg} \mathrm{g}^{-1}$ in untreated MY soil to $4.42 \mathrm{mg} \mathrm{g}^{-1}$ in the $\mathrm{H}_{2} \mathrm{O}_{2}$-treated soil (Table 3). In TA soil, the specific surface area of the $\mathrm{H}_{2} \mathrm{O}_{2}$-treated soil was $109 \mathrm{~m}^{2} \mathrm{~g}^{-1}$, remarkably less than the untreated soil (Table 2). The contribution of organic matter to soil surface area would be great. Fig. 1 shows that more DNA was adsorbed in the $\mathrm{H}_{2} \mathrm{O}_{2}$-treated TA soil than in the untreated soil. The adsorption maximum of the $\mathrm{H}_{2} \mathrm{O}_{2}$-treated TA soil, $4.71 \mathrm{mg} \mathrm{g}^{-1}$ was higher than that of the untreated soil, $3.19 \mathrm{mg} \mathrm{g}^{-1}$, although surface area was greatly decreased by the treatment. Also, the decrease in organic matter content of KB soil little affected DNA adsorption per unit weight, in the $\mathrm{H}_{2} \mathrm{O}_{2}$-treated soil particles (19). Similarly, $\mathrm{H}_{2} \mathrm{O}_{2}$-treatment of a clay fraction of Alfisol increased significantly DNA adsorption (2). From the present results, we conclude that soil organic matter has no positive influence on DNA adsorption.

As Table 2 shows that a small portion of organic matter is resistant even to $\mathrm{H}_{2} \mathrm{O}_{2}$ treatment, it is necessary to remove all organic matter from soil in order to assess DNA adsorption in organic matter-free soil particles. We compared DNA adsorption between TA andosol heated at $400^{\circ} \mathrm{C}$ and untreated soil to reveal the absolute contribution of soil organic matter to DNA adsorption. The heat treatment
Table 2. DNA adsorption maxima and chemical properties of the treated TA andosols

\begin{tabular}{lccc}
\hline & Untreated & $\begin{array}{c}\mathrm{H}_{2} \mathrm{O}_{2} \\
\text { treated }\end{array}$ & $\begin{array}{c}400^{\circ} \mathrm{C} \\
\text { heated }\end{array}$ \\
\hline Total carbon content (\%) & 8.25 & 2.17 & 0.03 \\
Acid oxalate extractable & & & \\
Al (\%) & 4.21 & 4.70 & 4.55 \\
Fe (\%) & 1.75 & 2.14 & 1.87 \\
Specific surface area $\left(\mathrm{m}^{2} \mathrm{~g}^{-1}\right)^{*}$ & 215 & 109 & 60.7 \\
DNA adsorption maximum per & 3.19 & 4.71 & 4.92 \\
$\quad$ weight (mg g $\left.{ }^{-1}\right) * *$ & 0.0148 & 0.0432 & 0.0811 \\
DNA adsorption maximum per & & & \\
$\quad$ surface area $\left(\mathrm{mg} \mathrm{m}^{-2}\right)$ & & & \\
\hline
\end{tabular}

* $\mathrm{N}_{2}$-BET method (Data from Saeki and Matsumoto (17)).

** estimated by the simple Langmuir equation.

reduced the soil T-C content to $0.03 \%$. The specific surface area of the heated soil was one third that of the original soil, and also less than that of the $\mathrm{H}_{2} \mathrm{O}_{2}$-treated soil (Table 2). Nevertheless, DNA adsorption was significantly greater in the heated TA soil than untreated soil (Fig. 1). The DNA adsorption maximum of the particles was raised from 3.19 $\mathrm{mg} \mathrm{g}^{-1}$ to $4.92 \mathrm{mg} \mathrm{g}^{-1}$ by the heat treatment. Moreover, DNA adsorption per specific surface area of the heated soil was 5 fold that of the original soil (Table 2).

These results suggested a negative relationship between soil organic matter content and the adsorption of DNA molecules in soils. Thus, we investigated the relationship between the T-C content and the estimated DNA adsorption maxima (Table 3) of all the soil samples used in the present study with a simple linear regression model. However, a statistical analysis of the data resulted in no correlation between the two values (Fig. 2).

Table 3. Estimated Langmuir equation parameters for each treated soil sample

\begin{tabular}{|c|c|c|c|c|c|}
\hline \multirow[t]{2}{*}{ Samples } & & $\begin{array}{l}\text { DNA adsorption } \\
\text { maxima }\end{array}$ & Constant & Correlation coefficient & Sample No. \\
\hline & & $A \max \left(\mathrm{mg} \mathrm{g}^{-1}\right)$ & $k$ & $r$ & $\mathrm{n}$ \\
\hline \multicolumn{6}{|l|}{ Andosol } \\
\hline \multirow{2}{*}{$\begin{array}{c}\text { Miyakonojyo } \\
\text { (MY) }\end{array}$} & untreated & 4.17 & 0.013 & $0.960(p<0.01)$ & 6 \\
\hline & $\mathrm{H}_{2} \mathrm{O}_{2}$ treated & 4.42 & 0.021 & $0.983(p<0.001)$ & 6 \\
\hline MY+slurry & untreated & 1.80 & 1.039 & $0.997(p<0.001)$ & 11 \\
\hline \multirow{2}{*}{$\begin{array}{c}\text { Tanashi } \\
\text { (TA) }\end{array}$} & $\mathrm{H}_{2} \mathrm{O}_{2}$ treated & 4.71 & 0.054 & $0.987(p<0.001)$ & 7 \\
\hline & $400^{\circ} \mathrm{C}$ heated & 4.92 & 0.222 & $0.995(p<0.001)$ & 7 \\
\hline \multirow{2}{*}{$\begin{array}{l}\text { Chiran } \\
\text { (CR) }\end{array}$} & untreated & 2.76 & 0.011 & $0.970(p<0.001)$ & 10 \\
\hline & $\mathrm{H}_{2} \mathrm{O}_{2}$ treated & 3.27 & 0.058 & $0.853(p<0.01)$ & 11 \\
\hline \multirow{2}{*}{$\begin{array}{l}\text { Kumamoto* } \\
\text { (KB) }\end{array}$} & untreated & 5.65 & 0.286 & $0.984(p<0.001)$ & 18 \\
\hline & $\mathrm{H}_{2} \mathrm{O}_{2}$ treated & 5.72 & 0.578 & $0.959(p<0.001)$ & 18 \\
\hline \multirow[t]{2}{*}{ Saga } & untreated & 2.76 & 0.091 & $0.995(p<0.001)$ & 10 \\
\hline & $\mathrm{H}_{2} \mathrm{O}_{2}$ treated & 2.69 & 0.081 & $0.993(p<0.001)$ & 18 \\
\hline \multicolumn{6}{|l|}{ Acrisol* } \\
\hline \multirow[t]{2}{*}{ Nagasaki } & untreated & 3.47 & 0.083 & $0.982(p<0.001)$ & 12 \\
\hline & $\mathrm{H}_{2} \mathrm{O}_{2}$ treated & 3.42 & 0.148 & $0.982(p<0.001)$ & 17 \\
\hline
\end{tabular}

\footnotetext{
* Data from our previous study (19).
} 


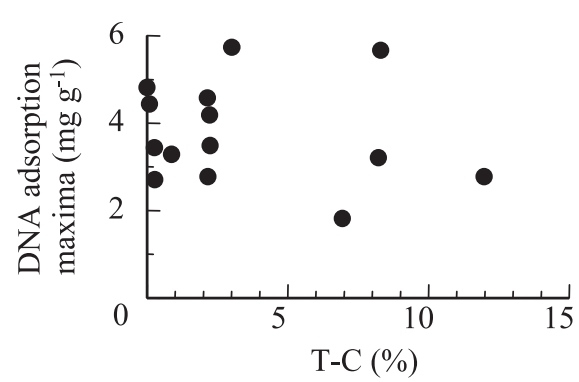

Fig. 2. The relationship between total carbon (T-C) content and DNA adsorption maxima estimated with the Langmuir equation.

\section{Discussion}

The contributions of soil organic matter to DNA adsorption

The DNA adsorption increased with the removal of organic matter by the treatment with $\mathrm{H}_{2} \mathrm{O}_{2}$ and heating at $400^{\circ} \mathrm{C}$ although surface area was greatly decreased by both treatments. Furthermore, the increase in soil organic matter due to the slurry had a clear negative influence on DNA adsorption in the soil. In summary, soil organic matter had no positive influence on DNA adsorption in the andosols. Ogram et al. (13) stated that the contribution of organic carbon content to the adsorption of DNA was very small. In soil in which the clay fraction was dominated by permanently charged minerals, organic matter seemed to make no contribution to DNA adsorption (1). The apparent increase in adsorption by $\mathrm{H}_{2} \mathrm{O}_{2}$-treatment and heating at $400^{\circ} \mathrm{C}$ would be caused by the formation of new adsorptive sites due to the appearance of $\mathrm{Al}$ and $\mathrm{Fe}$ oxides trapped in organic matter by these treatments.
Soil organic matter is composed of a variety of organic compounds. Among them, humic acids may be the only compounds which can be isolated from soils and supply solid surfaces for DNA adsorption. Nevertheless, there have been few reports about DNA adsorption by one representative material of soil organic matters, humic acids $(3,20)$. In weak-acidic conditions, DNA molecules were adsorbed by humic acid $(3,20)$. We also observed that a humic acid supplied by Wako Chemicals (Osaka, Japan) adsorbed a remarkable amount of the same DNA molecules as used in the present study (Saeki, unpublished data). Most (70 to 80\%) of the DNA adsorbed by the humic acid could not be extracted with distilled water, a $0.1 \mathrm{M} \mathrm{NaCl}$ solution, or DNA buffer ( $\mathrm{pH}$ 4.0) (3), implying that DNA molecules bind to the humic acid surface. The surface chemical properties of organic matter in situ may be considerably different from those of humic acids extracted from soils.

\section{Mechanisms and sites of DNA adsorption in andosols}

There are three possible mechanisms of DNA adsorption by soil particles. These mechanisms are, in fact, complicated although their contributions would depend greatly on the conditions. Phosphate groups on the edge of DNA molecule may bind via a ligand exchange reaction directly to $\mathrm{OH}$ groups of $\mathrm{Al}$ or $\mathrm{Fe}$ oxide minerals in soils, as illustrated in Fig. 3a. Some researchers have also considered that DNA molecules bind to $\mathrm{OH}$ groups on the edge of phyllosilicates such as montmorillonite $(9,11,15)$. A previous study (19) indicated that oxide minerals in soils are one of the most important adsorbents for DNA molecules, because adsorption was lowered when $\mathrm{Fe}$ or $\mathrm{Al}$ oxides including allophane were removed from the $\mathrm{H}_{2} \mathrm{O}_{2}$-treated soil by an acid-oxalate

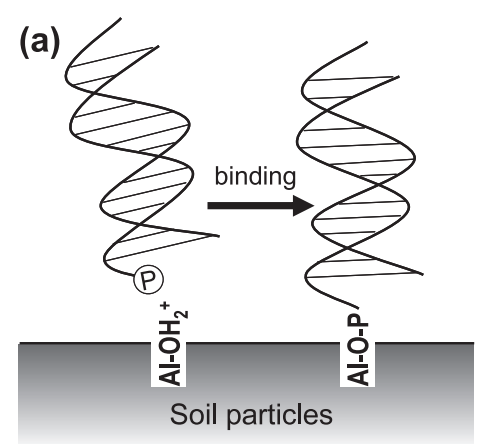

(P): phosphate groups

(c)

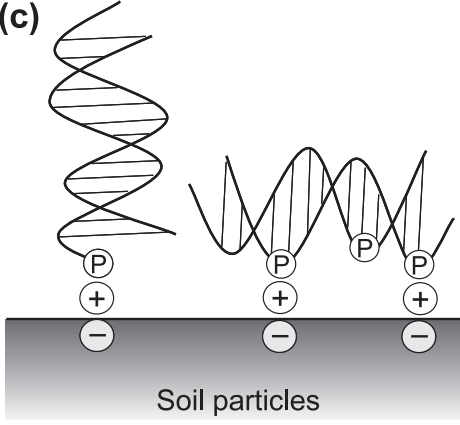

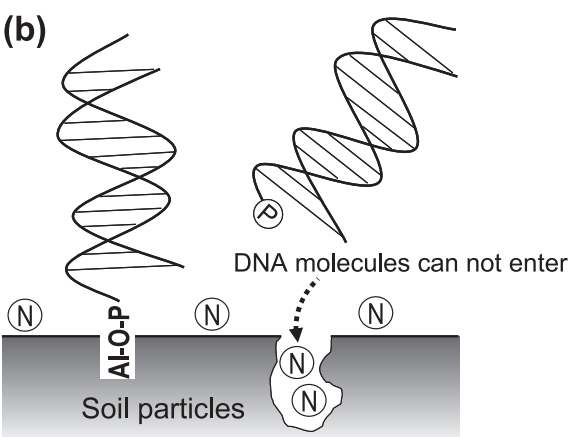

(N): nitrogen molecules

(d)

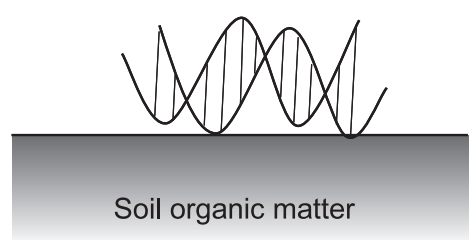

Fig. 3. Conceptual figures of DNA adsorption on soil particles. 
extraction. Khanna and Stotzky (9) and Paget et al. (15) suggested the adsorption mechanism shown in Fig. 3c, where the DNA molecules associate with the surface of negatively charged materials such as phyllosilicates via a bridging of cations. This mechanism of adsorption might possibly occur in soil organic matter. As shown in Fig. 3d, DNA molecules might directly bind to soil organic matter. However, we concluded that the DNA molecules were not likely to bind directly to the surface of the organic matter, given from that DNA adsorption increased with the removal of soil organic matter and decreased with the addition of organic materials to the soil.

The treatment with $\mathrm{H}_{2} \mathrm{O}_{2}$ and heating at $400^{\circ} \mathrm{C}$ removed most of the soil organic matter, resulting in a decrease in the apparent surface area of the soil (Table 2) because of the elimination of fine pores into which $\mathrm{N}_{2}$ molecules used to determine specific surface area, can enter. Nevertheless, DNA adsorption in the andosols increased with these treatments. There are two explanations for these results. First, the number of soil surface sites for DNA adsorption was not necessarily proportional to the specific surface areas of the soil because DNA molecules can not enter the small pores into which $\mathrm{N}_{2}$ molecules diffuse. This concept is illustrated in Fig. 3b. Ogram et al. (13) reported that more short strands of DNA molecules were more adsorbed on the soil particles than the long strands, while this event was not observed in the sand. They explained that it would be more difficult for the long strands of DNA to enter soil pores than the short strands. Second, these treatments form new adsorptive sites due to the appearance of $\mathrm{Al}$ and $\mathrm{Fe}$ oxides trapped in organic matter. Our previous study indicated that oxide minerals in soils are one of the most important adsorbents for DNA molecules (19). Consequently, DNA adsorption would depend on the qualitative conditions of the soil particle's surfaces rather than simply on the specific surface area of the particles. However, the only studies of DNA adsorption by oxide minerals have been with goethite (2) and silica (12). Studies with other oxide minerals such as allophane will be required to compare the behavior of extracellular DNA molecules in volcanic ash soils.

\section{Acknowledgements}

The authors thank Miss M. Morisaki, Mr. T. Morita and Miss A. Hamada for helping with the experiments. This research was supported by a Grant-in-aid for Scientific Research from the Japan Society for the Promotion of Science (subject number 19380044).

\section{References}

1. Cai, P., Q. Huang, and X. Zhang. 2006. Microcalorimetrc studies of the effects of $\mathrm{MgCl}_{2}$ concentrations and $\mathrm{pH}$ on the adsorption of DNA on montmorillonite, kaolinite and goethite. Appl. Clay Sci. 32:147152.

2. Cai, P., Q. Huang, X. Zhang, and H. Chen. 2006. Adsorption of DNA on clay minerals and various colloidal particles from an Alfisol. Soil Biol. Biochem. 38:471-476.

3. Crecchio, C., and G. Stotzky. 1998. Binding of DNA on humic acids: Effect on transformation of Bacillus subtilis and resistance to DNase. Soil Biol. Biochem. 30:1061-1067.

4. Greaves, M.P., and M.J. Wilson. 1969. The adsorption of nucleic acids by montmorillonite. Soil Biol. Biochem. 1:317-323.

5. Greaves, M.P., and M.J. Wilson. 1970. The degradation of nucleic acids and montmorillonite-nucleic-acid complexes by soil microorganisms. Soil Biol. Biochem. 2:257-268.

6. Hoshino, Y.T., and N. Matsumoto. 2004. An improved DNA extraction method using skim milk from soils that strongly absorb DNA. Microbes Environ. 19:13-19.

7. Howeler, M., W.C. Chiorse, and L.P. Walker. 2003. A quantitative analysis of DNA extraction and purification from compost. J. Microbiol. Methods 54:37-45.

8. Ikeda, S., H. Tsurumaru, S. Wakai, C. Noritake, K. Fujishiro, M. Akasaka, and K. Ando. 2008. Evaluation of the effects of different additives in improving the DNA extraction yield and quality from andosol. Microbes Environ. 23:159-166.

9. Khanna, M., and G. Stotzky. 1992. Transformation of Bacillus subtilis by DNA bound on montmorillonite and effect of DNase on the transforming ability of bound DNA. Appl. Environ. Microbiol. 58:1930-1939.

10. Khanna, M., M. Yoder, L. Calamai, and G. Stotzky. 1998. X-ray diffractometry and electron microscopy of DNA from Bacillus subtilis bound on clay minerals. Sci. Soils 3:1-10.

11. Lorenz, M.G., and W. Wackernagel. 1987. Adsorption of DNA to sand and variable degradation rates of adsorbed DNA. Appl. Environ. Microbiol. 53:2948-2952.

12. Melzak, K.A., C.S. Sherwood, R.F.B. Turner, and C.A. Haynes. 1996. Driving forces for DNA adsorption to silica in perchlorate solutions. J. Colloid Interface Sci. 181:635-644.

13. Ogram, A.V., M.L. Mathot, J.B. Harsh, J. Boyle, and C.A. Pettigrew, Jr. 1994. Effects of DNA polymer length on its adsorption to soils. Appl. Environ. Microbiol. 60:393-396.

14. Ogram, A., G.S. Sayler, D. Gustin, and R.J. Lewis. 1988. DNA adsorption to soils and sediments. Environ. Sci. Technol. 22:982-984.

15. Paget, E., L.J. Monrozier, and P. Simonet. 1992. Adsorption of DNA on clay minerals: Protection against DNase I and influence on gene transfer. FEMS Microbiol. Let. 97:31-40.

16. Pietramellara, G., M. Franchi, E. Gallori, and P. Nannipieri. 2001. Effect of molecular characteristics of DNA on its adsorption and binding on homoionic montmorillonite and kaolinite. Biol. Fertil. Soils 33:402-409.

17. Saeki, K., and S. Matsumoto. 1994. Influence of organic matter on selenite sorption by andosols. Commun. Soil Sci. Plant Anal. 25:3379-3391.

18. Saeki, K. 2008. The comparison of arsenic adsorptions on an andosol between arsenite and arsenate. Soil Sci. 173:248-256.

19. Saeki, K., M. Morisaki, and M. Sakai. 2008. The contribution of soil constituents to adsorption of extracellular DNA by soils. Microbes Environ. 23:353-355.

20. Stotzky, G. 2000. Persistence and biological activity in soil of insecticidal proteins from Bacillus thuringiensis and of bacterial DNA bound on clays and humic acids. J. Environ. Qual. 29:691-705.

21. Torsvik, V., J. Goksøyr, and F.L. Daae. 1990. High diversity in DNA of soil bacteria. Appl. Environ. Microbiol. 56:782-787. 